\section{Evapotranspiration-based Irrigation Scheduling for Container-grown Viburnum odoratissimum (L.) Ker Gawl.}

\author{
Jeff B. Million' ${ }^{1}$ and Thomas H. Yeager \\ Department of Environmental Horticulture, University of Florida, IFAS, \\ 1545 Fifield Hall, Gainesville, FL 32611-0670
}

\section{Joseph P. Albano}

U.S. Horticultural Research Laboratories, USDA, ARS, Ft. Pierce, FL 34945

Additional index words. controlled-release fertilizer, drainage, leaching, nutrient load, nitrogen, overhead, phosphorus, potassium, woody ornamental

\begin{abstract}
The capacity for evapotranspiration (ET)-based irrigation scheduling to reduce runoff volume and nutrient leaching was tested in Fall 2004 and Spring 2005. Runoff (container leachate plus unintercepted irrigation and precipitation) was collected continuously for 17 weeks during production of sweet viburnum [Viburnum odoratissimum (L.) Ker Gawl.] in 2.4-L (16-cm top diameter) containers fertilized with an $18 \mathrm{~N}-2.6 \mathrm{P}-10 \mathrm{~K}$ polymer-coated, controlled-release fertilizer. Treatments were a factorial arrangement of two irrigation rates (fixed rate of $1 \mathrm{~cm} \cdot \mathrm{d}^{-1}$ or a variable, ET-based rate) and two fertilizer rates (15 or $30 \mathrm{~g} /$ container in 2004 and 10 or $15 \mathrm{~g} /$ container in 2005). Averaged over the two experiments and compared with the $1-\mathrm{cm} \cdot \mathrm{d}^{-1}$ rate, ET-based irrigation reduced the amount of irrigation water applied (L/container) by $39 \%$ and runoff volume (L/container) by $42 \%$ with greatest reductions observed during the second half of the 2004 experiment and the first half of the 2005 experiment. Compared with $1-\mathrm{cm} \cdot \mathrm{d}^{-1}$ rate, ET-based irrigation reduced runoff nitrogen $(\mathrm{N})$, phosphorus $(\mathrm{P})$, and potassium $(\mathrm{K})(\mathrm{mg} /$ container) by $16 \%, 25 \%$, and $22 \%$, respectively, in 2004 and runoff $\mathrm{K} \mathbf{1 5 \%}$ in 2005 with irrigation effects varying on a weekly basis. Irrigation treatments did not affect the response of plants to fertilizer rate. Because shoot dry weight was unaffected by irrigation treatments, results indicate that compared with a fixed irrigation rate, ET-based irrigation can reduce irrigation and runoff volumes and to a lesser extent nutrient loss while providing adequate water for plant growth.
\end{abstract}

The container nursery industry is continuously seeking new irrigation and fertilization strategies to improve application efficiencies and reduce negative environmental impacts. The objective of these strategies is to strike a balance between the rewards of reduced water and fertilizer inputs and the risks of reduced plant growth and quality. One strategy to optimize irrigation entails supplying an amount of water that is proportional to that lost from ET. Water loss from ET can be measured directly by weighing representative containers or indirectly through monitoring substrate water potential. Estimations of ET can also be made with weather data and appropriate crop coefficients (Beeson, 1993, 2005, 2010; Schuch and Burger, 1997). Furthermore, irrigation can be withheld until substrate wa-

Received for publication 2 Aug. 2010. Accepted for publication 16 Sept. 2010

This research was supported by the Floral and Nursery Research Initiative, USDA, ARS, Specific Cooperative Agreement 58-6618-2-0208, CRIS 6618-13000-002-04S.

${ }^{1}$ To whom reprint requests should be addressed; e-mail jmillion@ufl.edu.
$\mathrm{NO}_{3}$-N losses (Fare et al., 1999). Constant feed fertilizer rates can generally be halved using ebb-and-flow subirrigation compared with overhead irrigation (Barrett, 1991) indicating that lower fertilizer rates may be possible with water-conserving irrigation practices. Huett (1997) indicated that occasional heavy precipitation can substantially reduce fertilizer nutrient buildup that can occur under minimal-leach irrigation treatments. This suggests that the potential for zero-leach or minimal-leach irrigation strategies to reduce nutrient leaching may be limited in regions with significant precipitation.

The objective of our research was to determine if an ET-based irrigation schedule could reduce irrigation runoff volume and nutrient loss compared with a fixed-rate irrigation schedule. The two irrigation schedules were evaluated using two controlledrelease fertilizer (CRF) application rates to determine if fertilizer efficiency could be increased with ET-based irrigation.

\section{Materials and Methods}

Experimental site. Experiments were conducted at the University of Florida in Gainesville (lat. $29^{\circ} 67^{\prime} \mathrm{N}$, long. $82^{\circ} 33^{\prime} \mathrm{W}$ ) in the Fall of 2004 and in the spring of 2005 and were similar in design to experiments previously reported (Million et al., 2007a, 2007b). The site consisted of four $6.1 \times 6.1-\mathrm{m}$ zones each irrigated with four rotary-drive sprinklers (Model PGP-ADJ with No. 2 Nozzle; Hunter Industries Inc., San Marcos, CA) operating at a regulated pressure of $270 \mathrm{kPa}$ and at a height of $150 \mathrm{~cm}$. We adjusted sprinkler irrigation patterns until Christiansen's uniformity coefficient (Haman et al., 1997) was greater than $90 \%$ for each irrigation zone. Sprinklers delivered water at $1.8 \mathrm{~cm} \cdot \mathrm{h}^{-1}$ with little variation between zones. Four $1.2 \times 1.2-\mathrm{m}$ platforms designed to collect runoff (container leachate plus unintercepted irrigation and precipitation) were placed within each of the four irrigation zones for a total of 16 platforms. Runoff was collected within an $89 \mathrm{~cm} \times 105-\mathrm{cm}\left(0.937 \mathrm{~m}^{2}\right)$ area of each platform leaving $0.6 \mathrm{~m}^{2}$ for border plants. There were no border plants on the lower edge of the collection area to allow uninterrupted flow of runoff into the collection vessel. Platforms were covered with standard nursery-grade polypropylene groundcloth underlain with one layer of $1.1-\mathrm{mm}$ thick pond liner (PondGard; Firestone Building Products, Carmel, IN) to direct runoff water into a collection vessel. Three sections of $1.3-\mathrm{cm}-$ diameter pipe were fastened underneath the pond liner to delineate the collection area from the border area. Two 9.5-cm-diameter cups attached to each platform and maintained at the top of the canopy were used to measure daily inputs of irrigation water and precipitation. An on-site weather station (Vantage Pro Plus ${ }^{\circledR}$ 6162; Davis Instruments Co., Hayward, CA) measured daily minimum and maximum air temperatures $\left({ }^{\circ} \mathrm{C}\right)$, solar radiation $\left(\mathrm{MJ} \cdot \mathrm{m}^{-2}\right)$, and rainfall $(\mathrm{mm})$. Data from the Florida Automated Weather Network's (FAWN; http://fawn.ifas.ufl.edu/) Alachua 
weather station were used to fill any voids in weather data.

Planting detail. The container substrate was a mixture of 2 aged pine bark: 1 sphagnum peatmoss: 1 coarse builder's sand (by volume). The pine bark passed a screen with $2.54-\mathrm{cm}$ openings. During mixing, the substrate was amended with $4.1 \mathrm{~kg} \cdot \mathrm{m}^{-3}$ of dolomitic limestone (James River Limestone Co., Buchanan, VA) and $0.6 \mathrm{~kg} \cdot \mathrm{m}^{-3}$ of a micronutrient blend (Micromax; Scotts Co., Marysville, $\mathrm{OH}$ ). Black, polyethylene, blow-molded, 16-cm top diameter containers (Elite 300; ITML Horticultural Products, Brantford, Ontario, Canada) were filled to a final substrate volume of 2.4 L. The available water-holding capacity of this substrate on a volumetric basis is $\approx 25 \%$ or 600 $\mathrm{mL}$ per $2.4 \mathrm{~L}$ of substrate. This value is the maximum amount of water we have observed large, established plants to be able to remove from this substrate under conditions of high ET demand. Containers were fertilized with a resincoated, 18N-2.6P-10K CRF (Osmocote Classic 18-6-12, 8-9 month release at $21^{\circ} \mathrm{C}$; Scotts Co.) at either $15 \mathrm{~g}$ (FRT15) or $30 \mathrm{~g}$ (FRT30) in 2004 and either $10 \mathrm{~g}$ (FRT10) or $15 \mathrm{~g}$ (FRT15) in 2005. According to the label, this CRF contained $15 \%, 2.2 \%$, and $8.3 \%$ coated, slowrelease $\mathrm{N}, \mathrm{P}$, and $\mathrm{K}$, respectively. The CRF was derived from ammonium nitrate, ammonium phosphate, calcium phosphate, and potassium sulfate and contained $8 \% \mathrm{NO}_{3}-\mathrm{N}$ and $10 \%$ $\mathrm{NH}_{4}-\mathrm{N}$. CRF was incorporated on an individual container basis just before planting.

Stem cuttings of sweet viburnum [Viburnum odoratissimum (L.) Ker Gawl.] rooted in 180 -mL containers ( 32 per standard tray) were transplanted one per container on 23 Aug. 2004 and 10 Mar. 2005. The substrate used for rooting stem cuttings was a commercial mix (Metro Mix 510LL; Sun Gro Horticulture, Bellevue, WA) comprised of pine bark, sphagnum peatmoss, vermiculite, and bark ash. Containers were placed on platforms at 32 per $\mathrm{m}^{2}$ (30 per runoff collection area) in a square arrangement. Containers were spaced at the end of Week 10 (2004) and Week 13 (2005) to 16 per $\mathrm{m}^{2}$ (15 per runoff collection area) by removing every other container.

Initial watering-in of transplants. Transplants were watered-in using a hose and breaker nozzle. The volume of water applied was determined by multiplying the time of irrigation times the nozzle flow rate. The volume of runoff from this initial watering was determined by weighting and samples were taken for nutrient analyses. The same amount of water was applied to three containers containing unfertilized substrate to assess the contribution of the substrate to runoff nutrients during watering-in of the transplants. Two water samples were collected at the same time to provide background levels of $\mathrm{N}, \mathrm{P}$, and $\mathrm{K}$ in irrigation water. The irrigation and runoff amounts from watering-in were not included in the overall analysis of irrigation and runoff during the two experiments.

Irrigation, evapotranspiration, and plant capture factor. Plants were irrigated predawn (usually at $0500 \mathrm{HR}$ ) with either a fixed rate of $1 \mathrm{~cm} \cdot \mathrm{d}^{-1}$ of water $(1 \mathrm{CM})$ or a variable amount of water based on the substrate moisture deficit before irrigation (ETI). Soil moisture deficit (SMD) was the amount of water required to bring a container's substrate water content back to container capacity and was determined by weighing each of eight containers in the evening (usually $1600 \mathrm{HR}$ but often later). Container weights at container capacity were adjusted several times during the season to account for increases that occurred from plant growth and any changes in substrate water retention properties. This adjustment was made after greater than $2 \mathrm{~cm}$ of precipitation occurred when all containers were assumed to be at container capacity. Containers were weighed 1 to $2 \mathrm{~h}$ after irrigation and drainage (usually at $0800 \mathrm{HR}$ ), which provided initial wet weights for ET determinations and verified that containers were being watered to container capacity. ET was estimated by subtracting the container weight at the end of the day when solar radiation levels were low (usually between $0500 \mathrm{HR}$ and 0800 HR depending on the time of year) from the post-irrigation container weight. ET volume $\left(\mathrm{cm}^{3} /\right.$ container) was converted to ET depth ( $\mathrm{cm} /$ container) by dividing ET volume by 200 $\mathrm{cm}^{2}$, the top area of the container. For ETI in 2004, irrigation was applied daily and irrigation run times were adjusted manually to deliver $100 \%$ of SMD. In 2005, ETI irrigation was not applied if SMD was less than $1.0 \mathrm{~cm}$ $\left(200 \mathrm{~cm}^{3} /\right.$ container). Once this threshold was reached, irrigation was adjusted manually to supply $100 \%$ of SMD. A rain sensor (MiniClik; Hunter Industries, Cary, NC) automatically shut off irrigation, regardless of irrigation treatment, if precipitation exceeded $1.25 \mathrm{~cm}$ during both 2004 and 2005 experiments.

ETI rates were adjusted to account for the influence of the plant canopy on irrigation capture. An irrigation capture factor was determined every 3 weeks on 16 containers per irrigation treatment (four per platform). We randomly chose the containers for these tests at the beginning of the experiment and we determined the irrigation capture factor on the same 32 containers throughout each experiment. For Week 10 in 2004 and Week 13 in 2005, irrigation capture factor determinations were made after spacing containers. For irrigation capture determinations, containers weighed to the nearest gram were placed in 2.5-L plastic leachate collection tubs $(16.5 \mathrm{~cm}$ top diameter) and a plastic "skirt" was attached to keep irrigation water from entering directly into the collection tub. The assemblies were then placed back onto the runoff platforms. After irrigation, containers were reweighed and the volume of water retained by each container was determined by subtracting the pre-irrigation weight. Volume of leachate collected in each tub was also measured. An irrigation capture factor $(\mathrm{CF})$ was calculated as:

$$
\begin{aligned}
\mathrm{CF}= & {\left[\text { leachate }\left(\mathrm{cm}^{3}\right)\right.} \\
& \left.+ \text { water retained }\left(\mathrm{cm}^{3}\right)\right] / \\
& \text { water applied }\left(\mathrm{cm}^{3}\right)
\end{aligned}
$$

Water applied was the volume of irrigation water that would be intercepted by the container without any canopy effect and was equal to the depth of irrigation water applied $(\mathrm{cm})$ multiplied by the container's top area $\left(200 \mathrm{~cm}^{2}\right)$. Values for CF were subsequently used to adjust ETI rates according to: ETI $(\mathrm{cm})=\mathrm{SMD}(\mathrm{cm}) / \mathrm{CF}$.

Runoff and plant data collection. Runoff collected continuously from platforms was measured on a weekly basis and runoff volume reported on an area basis $\left(\mathrm{L} \cdot \mathrm{m}^{-2}\right)$. Because water samples were collected once per week, some volatilization loss of $\mathrm{N}$ may have occurred between weekly collections. The extent of this potential loss of $\mathrm{N}$ was not determined. No attempt was made to distinguish the relative contributions of leachate versus unintercepted irrigation water. Water samples from each weekly runoff collection as well as water samples from initial watering-in of transplants were filtered (Whatman No. 40; Fisher Scientific, Pittsburgh, PA; http://www. fishersci.com) and stored frozen until nutrient analyses were performed. Although sample filtering may have excluded the measurement of nutrient loss associated with particulates greater than $0.8 \mu \mathrm{m}$, filtering was necessary to prevent potential damage to analytical instruments.

As a result of hurricanes affecting the experiment in 2004, plants were moved into a glass-covered greenhouse during Week 3 and for several days during both Week 4 and Week 5. While in the greenhouse, we handwatered containers so that little if any leaching occurred; no runoff was collected. As a result, runoff during these three periods of 2004 was either zero (Week 3) or reduced (Weeks 4 and 5).

Plant canopy dimensions were measured every 3 weeks on the same five plants per platform. Plant height was the distance from the substrate surface to the uppermost foliage and plant width was the average of two perpendicular measurements. Plant size index was calculated as the average of plant height and width. Experiments were ended on 20 Dec. 2004 and 8 July 2005, 17 weeks after transplanting. At this time, plant size index and shoot dry weight were determined on all 15 plants per platform.

Runoff solutions were analyzed for $\mathrm{NO}_{3}$ $\mathrm{N}$, total Kjehldahl N (TKN), total P, and K by the Analytical Research Laboratory, Univ. of Florida, Gainesville (http://arl.ifas.ufl.edu/). Under typical conditions, the relative amount of nitrite $\mathrm{N}\left(\mathrm{NO}_{2}-\mathrm{N}\right)$ versus nitrate $\mathrm{N}\left(\mathrm{NO}_{3}-\mathrm{N}\right)$ is small (Fernandez-Escobar et al., 2004; Moutonnet and Fardeau, 1997), so that although the $\mathrm{NO}_{3}-\mathrm{N}$ analysis includes both forms of these forms of $\mathrm{N}$, for the purposes of this article, we refer to this amount as nitrate $\mathrm{N}\left(\mathrm{NO}_{3}-\mathrm{N}\right)$. TKN analyses did not include $\mathrm{NO}_{3}-\mathrm{N}$. N concentration was calculated as the sum of $\mathrm{NO}_{3}-\mathrm{N}$ and TKN concentrations. Weekly $\mathrm{N}, \mathrm{P}$, and $\mathrm{K}$ loads $\left(\mathrm{g} \cdot \mathrm{m}^{-2}\right)$ in runoff were calculated by multiplying weekly $\mathrm{N}, \mathrm{P}$, and $\mathrm{K}$ concentrations by weekly runoff volumes. Weekly N, P, and $\mathrm{K}$ loss in runoff on a per-container basis was calculated by dividing weekly nutrient load by the container density (containers per $\mathrm{m}^{2}$ ) for that week. 
For runoff volume and concentrations, amounts, and loads of $\mathrm{N}, \mathrm{P}$, and $\mathrm{K}$ in runoff which were collected on a weekly basis, the experiment was analyzed as a split-split plot design with two blocks, two irrigation treatments as main plots, two fertilizer treatments as split plots, and 17 weekly repeated measurements as split-split plots. Because week by irrigation and week by fertilizer interaction effects were found for most response variables, a separate analysis of variance (ANOVA) was conducted for each week to help determine how the treatment response changed over time. All ANOVA tests were conducted using the PROC GLM procedure

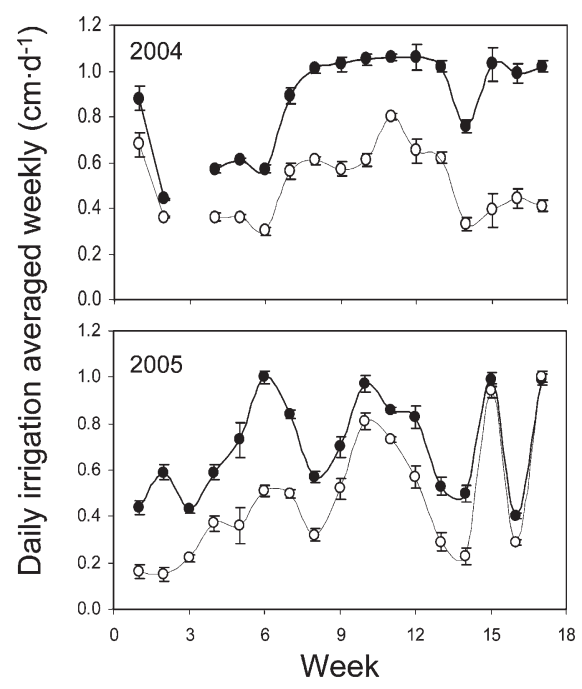

Fig. 1. Daily irrigation rates averaged weekly during 17 weeks of growing Viburnum odoratissimum in 2.4-L containers sprinkler-irrigated with either a fixed rate of $1 \mathrm{~cm} \cdot \mathrm{d}^{-1}(\mathbf{O})$ or evapotranspiration-based schedule $(\bigcirc)$. Irrigation was not applied if the past day's rainfall exceeded $1.25 \mathrm{~cm}$. Means are averaged over two fertilizer rates $(n=8)$. Error bars represent a $95 \%$ confidence interval $\left( \pm \mathrm{t}_{0.05,8} * \mathrm{SE}\right)$ around the mean. of the Statistical Analysis System (Version 8; SAS $^{\circledR}$ Institute, Cary, NC). For plant size and irrigation capture factors that were measured every 3 weeks, a similar ANOVA was made except that there were only seven subplot measurement dates. Final plant size index and shoot dry weight parameters were analyzed as a split-plot design. Treatment effects with $P<0.05$ were considered to be statistically significant.

\section{Results and Discussion}

Irrigation and evapotranspiration. ETI reduced the amount of irrigation water applied during both experiments (Fig. 1). Total irrigation water applied was $92 \mathrm{~cm}$ for $1 \mathrm{CM}$ and $52 \mathrm{~cm}$ for ETI in 2004 and $89 \mathrm{~cm}$ for $1 \mathrm{CM}$ and $59 \mathrm{~cm}$ for ETI in 2005. Compared with $1 \mathrm{CM}$, ETI reduced total water applied by $44 \%$ in 2004 and by $34 \%$ in 2005 for an average reduction of $39 \%$. ETI had less of an effect on irrigation amounts applied in 2005 than in 2004. We attributed this to greater precipitation in 2005 (Fig. 2) and to greater ET values in the second half of 2005 (Fig. 3), which resulted in irrigation rates for ETI that were similar to those of 1CM (Fig. 1).

ET measurements (Fig. 3) showed that daily ET values for 2004 followed a different pattern than those for 2005. For the first $60 \mathrm{~d}$, daily ET values were similar for both experiments, generally falling in the range of 0.5 to $0.8 \mathrm{~cm} /$ container. However, for the second half of the experiments, daily ET values for 2004 ranged from 0.3 to $1.2 \mathrm{~cm} /$ container, whereas values for 2005 ranged from 0.5 to $2.4 \mathrm{~cm} /$ container with less day-to-day variability in 2005 compared with 2004. To calculate equivalent ET values on a production area basis $(\mathrm{cm})$, divide container ET values ( $\mathrm{cm} /$ container) by 1.6 before spacing containers and divide by 3.2 after spacing containers. Higher ET rates during the second half of 2005 experiment coincided with the transition of spring to summer with associated increases in temperature and solar radi-

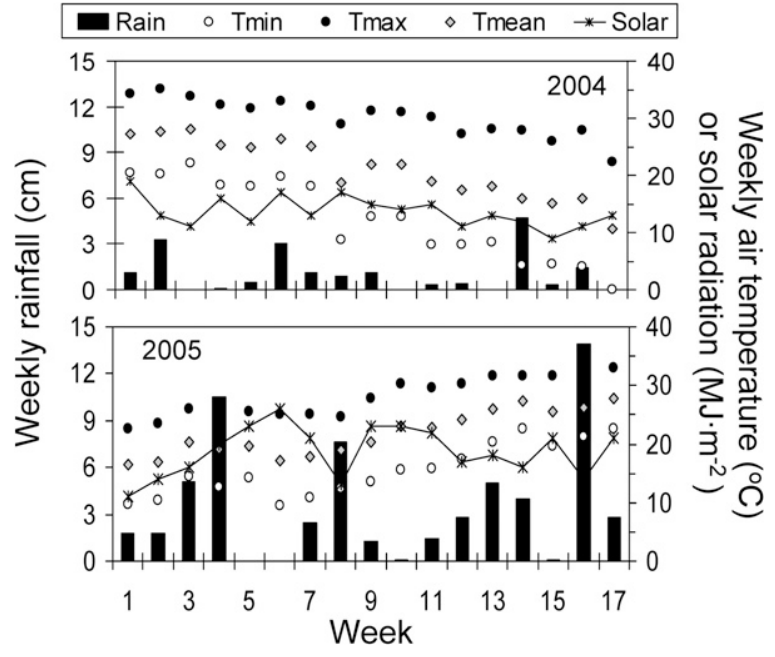

Fig. 2. Weekly precipitation totals and daily air temperatures (T) and solar radiation averaged weekly during 2004 and 2005 experiments. Plant dates were 23 Aug. 2004 and 10 Mar. 2005. ation. Conversely, relatively low and more variable ET values during the second half of 2004 reflected the seasonal effects of late fall and early winter on lowering temperatures and reducing solar radiation levels.

Irrigation capture. The ability of the sweet viburnum plant canopy to capture irrigation water that would normally fall between containers played an important role in reducing ETI rates in both experiments. The capture factor ranged from 1 during the first 6 to 8 weeks of each experiment to 2.3 and 2.5 by the end of 2004 and 2005, respectively (Fig. 4). Theoretical maximum CF values in this experiment were 1.6 and 3.2 for the 32 and 16 containers $/ \mathrm{m}^{2}$ spacings, respectively. Measured increases in CF during the two experiments were related to increases in plant size index (Fig. 5). Beeson and Yeager (2003) reported CF values for sweet viburnum in 11.4-L containers ranging between 0.5 and 1.5. The authors observed higher $\mathrm{CF}$ values as containers were placed in wider spacing arrangements. CF values for Rhododendron and Pittosporum sp. were less than 1 (Beeson and Knox, 1991), indicating that the canopies of these two species tended to "shed" irrigation water rather than "accumulate" it. More research is needed to better quantify irrigation capture as results here show that, at least for sweet viburnum, CF can be very significant and that considerably less irrigation water need be applied than amounts indicated solely by substrate moisture deficit.

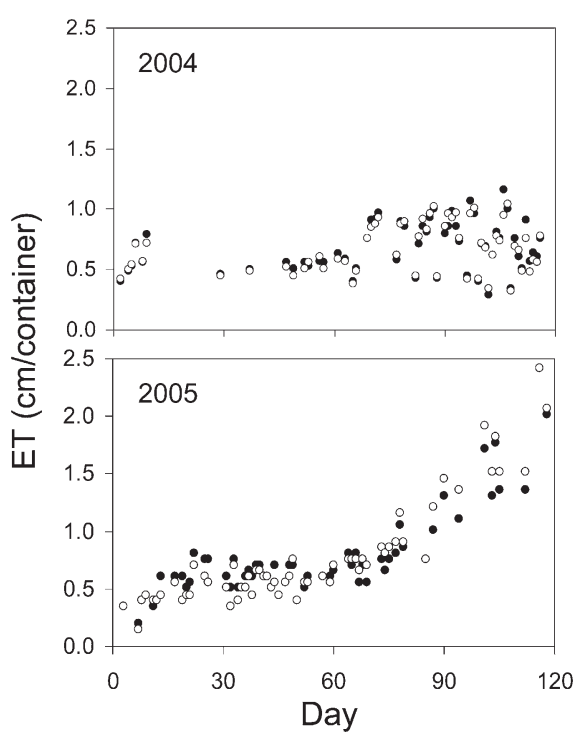

Fig. 3. Container evapotranspiration (ET) measured on weekdays without precipitation during 2004 and 2005 experiments. Viburnum odoratissimum liners were transplanted 23 Aug. 2004 and 10 Mar. 2005 into 2.4-L containers and sprinkler-irrigated with either a fixed rate of $1 \mathrm{~cm} \cdot \mathrm{d}^{-1}(\bullet)$ or a variable, ET-based rate $(\bigcirc)$ that was proportional to substrate water deficit. ET water loss was determined by weighing containers after early morning irrigation and again in the evening $(\mathrm{n}=8)$. Container ET unit of $1 \mathrm{~cm} /$ container is equivalent to $200 \mathrm{~mL}$ per container $\left(200-\mathrm{cm}^{2}\right.$ top area). 


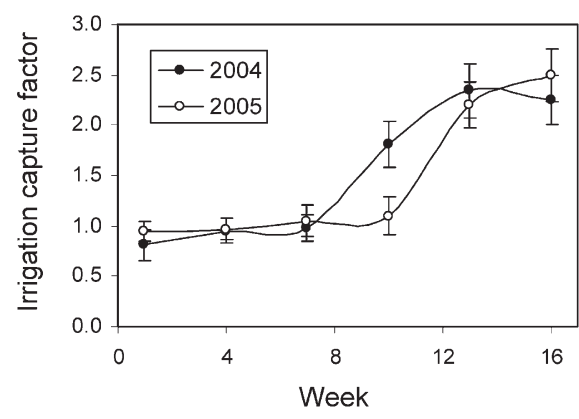

Fig. 4. Irrigation capture factor $(\mathrm{CF})$ measured periodically during production of Viburnum odoratissium in 2.4-L (16-cm top diameter) containers. CF describes the amount of water captured by the container with a plant in it relative to the amount of water that would be captured by the container without a plant in it. Means were averaged over two irrigation treatments and two fertilizer rates $(n=16)$. Vertical bars represent $95 \%$ confidence intervals $\left( \pm \mathrm{t}_{0.05,9} * \mathrm{SE}\right)$ around mean values.

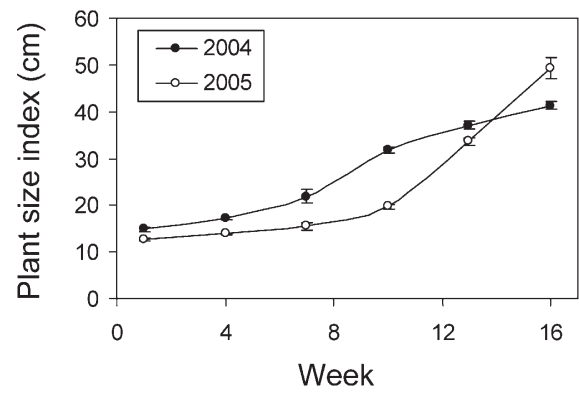

Fig. 5. Viburnum odoratissimum plant size index (average of height and width) during 2004 and 2005 experiments. Plant dates were 23 Aug. 2004 and 10 Mar. 2005. Means were averaged over two irrigation treatments and two fertilizer rates $(\mathrm{n}=80)$. Vertical bars represent $95 \%$ confidence intervals $\left( \pm \mathrm{t}_{0.05,73}{ }^{*} \mathrm{SE}\right)$ around mean values.

Precipitation. Greater amounts of precipitation fell in $2005(62 \mathrm{~cm})$ than in 2004 (18 cm; Fig. 2). Average precipitation amounts for these times of the year are $46 \mathrm{~cm}$ (2004) and $49 \mathrm{~cm}$ (2005) according to the FAWN database for the Alachua County weather station (Florida Automated Weather Network, 2010). Low precipitation in 2004 was the result of, in part, moving containers under cover during hurricane events. Of the $62 \mathrm{~cm}$ of precipitation that fell in $2005,42 \mathrm{~cm}$ or $68 \%$ fell during Weeks $3,4,8,13$, and 16 . Of these 5 weeks, rainfall amounts were particularly large during Week $4(11 \mathrm{~cm})$ and Week $16(14 \mathrm{~cm})$. Total water inputs (precipitation plus irrigation) for $1 \mathrm{CM}$ and ETI, respectively, were 110 and $70 \mathrm{~cm}$ in 2004 and 141 and $112 \mathrm{~cm}$ in 2005 .

Runoff. For both 2004 and 2005 experiments, the effect of irrigation schedule on runoff volume depended on the week of runoff collection (Fig. 6); fertilizer rate had no effect. ETI reduced runoff compared with CM1 during both experiments. When averaged over the two fertilizer rates, ETI reduced total

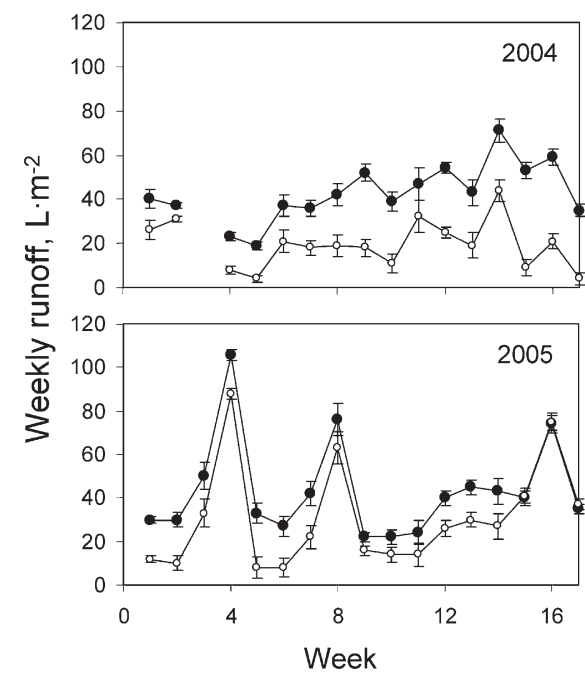

Fig. 6. Weekly runoff collected during production of sweet viburnum in 2.4-L containers sprinklerirrigated with either a fixed rate of $1 \mathrm{~cm} \cdot \mathrm{d}^{-1}(\bullet)$ or a variable, evapotranspiration (ET)-based rate that was proportional to substrate water deficit. ET-based irrigation reduced runoff volume for each week of the 2004 experiment and for all weeks except Weeks 8, 15, 16, and 17 of the 2005 experiment. Weekly means were averaged over two fertilizer rates $(n=8)$. Vertical bars represent $95 \%$ confidence intervals $\left( \pm \mathrm{t}_{0.05,8}{ }^{*} \mathrm{SE}\right)$ around mean values.

runoff by $55 \%$ ( 310 versus $\left.690 \mathrm{~L} \cdot \mathrm{m}^{-2}\right)$ in 2004 and by $30 \%\left(520\right.$ versus $\left.740 \mathrm{~L} \cdot \mathrm{m}^{-2}\right)$ in 2005. Reductions in runoff resulting from ETI relative to $\mathrm{CM} 1$ were greater during the second half of 2004 experiment when reduced ET associated with the onset of winter weather resulted in ETI rates that were lower than $1 \mathrm{~cm} \cdot \mathrm{d}^{-1}$. In contrast, reductions in runoff resulting from ETI were greater during the first half of the 2005 experiment when ET was relatively low as a result of cooler weather.

Plant growth. In general, plant growth was little affected by irrigation and fertilizer treatments during either experiment. In 2004, final plant height, width, and plant size index averaged 42,40 , and $41 \mathrm{~cm}$, respectively, and each was unaffected by treatments. Shoot dry

Table 1. Volume and nutrient concentration of runoff collected during watering-in of transplanted Viburnum odoratissimum liners into $2.4-\mathrm{L}$ (16.3-cm top diameter) containers. ${ }^{\mathrm{z}}$

\begin{tabular}{|c|c|c|c|c|c|}
\hline \multirow[b]{2}{*}{ Expt. } & \multirow{2}{*}{$\begin{array}{l}\text { Fertilizer rate } \\
\text { (g/container) }\end{array}$} & \multirow{2}{*}{$\begin{array}{l}\text { Watering-in runoff } \\
\text { (L/container) }\end{array}$} & \multicolumn{3}{|c|}{ Nutrient concn in runoff $\left(\mathrm{mg} \cdot \mathrm{L}^{-1}\right)$} \\
\hline & & & Nitrogen $^{y}$ & Phosphorus & Potassium \\
\hline \multirow[t]{5}{*}{2004} & 15 & 1.8 & 51 & 3.4 & 32 \\
\hline & 30 & 1.7 & 90 & 5.8 & 43 \\
\hline & & Fertilizer effect & $* *$ & $* *$ & NS \\
\hline & Unfertilized substrate ${ }^{\mathrm{x}}$ & 2.0 & $3(1)$ & $0.4(0.1)$ & $22(11)$ \\
\hline & Water & - & $0(0)$ & $0.0(0.0)$ & $1(0)$ \\
\hline \multirow[t]{5}{*}{2005} & 10 & 0.5 & 19 & 1.4 & 47 \\
\hline & 15 & 0.5 & 25 & 1.9 & 53 \\
\hline & & Fertilizer effect & $*$ & NS & NS \\
\hline & Unfertilized substrate $^{\mathrm{x}}$ & 0.7 & $2(0)$ & $0.1(0.0)$ & $26(4)$ \\
\hline & Water $^{\mathrm{x}}$ & - & $0(0)$ & $0.0(0.0)$ & $0(0)$ \\
\hline
\end{tabular}

${ }^{\mathrm{z}}$ For the 2004 experiment, $4.6 \mathrm{~cm}$ of precipitation (equivalent to $0.9 \mathrm{~L} /$ container) fell during watering-in period. A polymer-coated, $18 \mathrm{~N}-2.6 \mathrm{P}-10 \mathrm{~K}$, controlled-release fertilizer was incorporated into the container substrate immediately before transplanting. Means ( \pm SD) are averages of watering-in runoff collected from eight (two irrigation treatments $\times$ four replications) $0.94-\mathrm{m}^{2}$ platforms each containing 30 containers.

${ }^{\mathrm{y}} \mathrm{NO}_{3}-\mathrm{N}+$ total Kjeldahl $\mathrm{N}$ (TKN analysis did not include $\left.\mathrm{NO}_{3}-\mathrm{N}\right)$.

${ }^{\mathrm{x}}$ Control, $\mathrm{n}=3$ (unfertilized substrate) and $\mathrm{n}=2$ (water); mean (SD).

Ns, *,** Non-significant or significant at $P \leq 0.05$ or 0.01 , respectively. 
during initial watering-in of transplants. Unfertilized substrate contributed relatively low amounts of $\mathrm{N}$ and $\mathrm{P}$ in watering-in runoff but $\mathrm{K}$ leaching was significant (Table 1). No tests were conducted to see how $\mathrm{K}$ leaching from unfertilized substrate changed over time. Results from collecting watering-in runoff suggest that despite using CRF, significant nutrient loss can occur during watering-in and water should not be indiscriminately applied at this time.

Nutrient loss in runoff. In both experiments, the effect of irrigation treatment on runoff nutrient loss depended on the week runoff was collected (Fig. 7). Although the week by fertilizer rate interaction effect was significant, only results for FRT15 are included in Figure 7 because FRT15 was common to both experiments and the week by irrigation by fertilizer rate interaction effect was not significant. ANOVA conducted on a weekly basis indicated that ETI had a significant effect on decreasing $\mathrm{N}$ leaching loss (mg/container) compared with CM1 for Weeks 4, 5, 9, 10, 14, 15, and 17 in 2004 and Weeks 1 through 6,9 , and 15 in 2005 . In 2004, the greatest reductions in $\mathrm{N}$ leaching loss resulting from ETI compared with CM1 were observed during Weeks 4 and 5. Similar patterns of nutrient loss in runoff were observed for $\mathrm{P}$ and $\mathrm{K}$ as were observed for N. Compared with 2004 when nutrient loss toward the end of the experiment was diminishing, considerably greater loss of nutrients occurred during the last 4 to 5 weeks of 2005. This late-season increase in nutrient loss for 2005 was associated with increasing air temperatures (Fig. 2). Higher air temperatures likely resulted in higher substrate temperatures resulting in more rapid release of nutrients from CRF during this period (Huett and Gogel, 2003). In contrast, temperatures at the end of 2004 were decreasing and nutrient release would be expected to decrease as well.

ETI reduced cumulative runoff nutrient loss compared with CM1 in both 2004 and 2005 experiments (Table 2). For FRT15 and compared with CM1, ETI reduced total losses of $\mathrm{N}$ by $19 \%$, P by $27 \%$, and $\mathrm{K} 25 \%$ in 2004 and $\mathrm{N}$ by $10 \%$, $\mathrm{P}$ by $16 \%$, and $\mathrm{K}$ by $16 \%$ in 2005 . $\mathrm{NO}_{3}-\mathrm{N}$ represented $77 \%$ to $80 \%$ of $\mathrm{N}$ in 2004 and $79 \%$ to $85 \%$ of $\mathrm{N}$ in 2005 and was therefore the predominant form of $\mathrm{N}$ in runoff. These $\mathrm{NO}_{3}-\mathrm{N}$ percentages were higher than the $65 \%$ to $71 \%$ reported for two related runoff experiments (Million et al., 2007a, 2007b).

Although ETI decreased cumulative N, P, and $\mathrm{K}$ loss in runoff $(\mathrm{mg} /$ container $)$ compared with $1 \mathrm{CM}$, average volume-weighted concentrations of $\mathrm{N}, \mathrm{P}$, and $\mathrm{K}$ in runoff were increased. This was a result of ETI reducing irrigation volume (L/container) to a greater extent than it reduced nutrient leaching losses (mg/container) during each experiment (Table 2). For example, when averaged over both years for FRT15 and compared with CM1, ETI increased average runoff $\mathrm{N}$ concentration from 27 to $39 \mathrm{mg} \cdot \mathrm{L}^{-1}, \mathrm{NO}_{3}-\mathrm{N}$ from 22 to $33 \mathrm{mg} \cdot \mathrm{L}^{-1}, \mathrm{P}$ from 3.1 to $4.1 \mathrm{mg} \cdot \mathrm{L}^{-1}$, and $\mathrm{K}$ from 22 to $29 \mathrm{mg} \cdot \mathrm{L}^{-1}$.

Nutrient loads (Table 3 ) express runoff nutrient loss on an area basis, which may be useful in evaluating the potential amounts of nutrients that can move away from a given amount of production area. Unlike nutrient loss on a container basis, nutrient load values depend on the container density at the time leaching losses occur. As was observed for nutrient loss on a container basis, the effect of

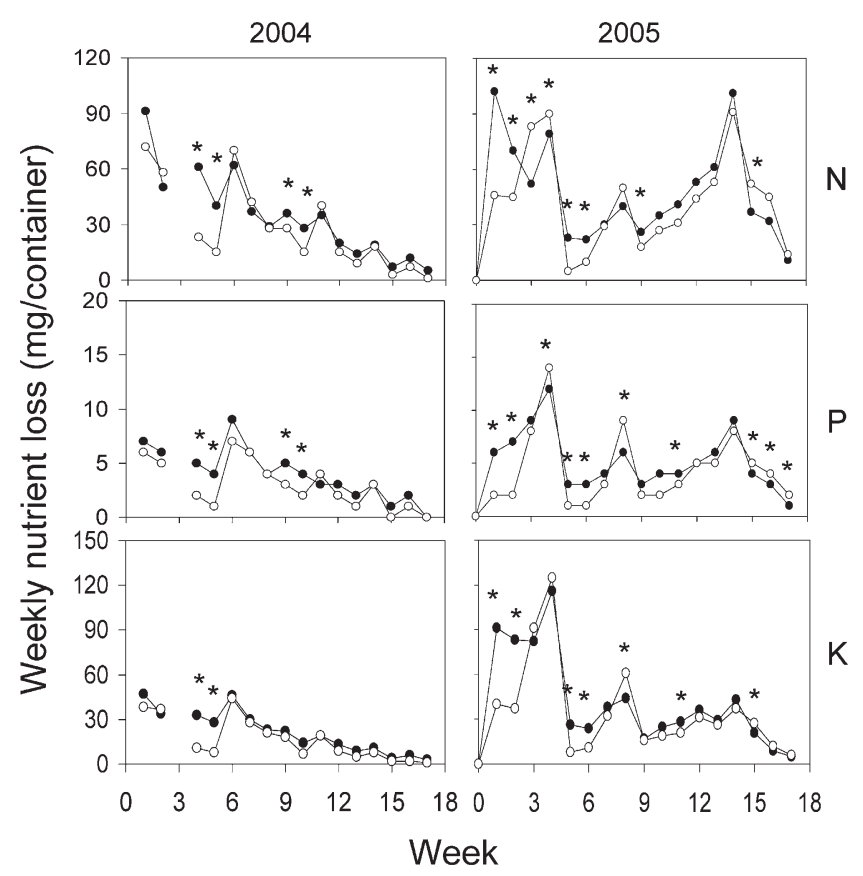

Fig. 7. Weekly amounts of nitrogen $(\mathrm{N})$, phosphorus $(\mathrm{P})$, and potassium $(\mathrm{K})$ in runoff collected continuously during 17 weeks of sweet viburnum production in 2.4-L containers. Sprinkler irrigation water was applied at either a fixed rate of $1 \mathrm{~cm} \cdot \mathrm{d}^{-1}(\bullet)$ or a variable, evapotranspiration $(E T)$-based rate $(\mathrm{O})$ that was proportional to substrate water deficit. An $18 \mathrm{~N}-2.6 \mathrm{P}-10 \mathrm{~K}$, polymer-coated, controlledrelease fertilizer was incorporated at $15 \mathrm{~g} /$ container immediately before planting. Asterisk denotes a significant $(P<0.05)$ irrigation effect for that week.

Table 2. Nutrient loss in runoff collected continuously during 17 weeks of growing Viburnum odoratissimum in $2.4-\mathrm{L}$ containers. $^{\mathrm{z}}$

\begin{tabular}{|c|c|c|c|c|c|c|}
\hline \multicolumn{2}{|c|}{ Treatment } & \multirow{3}{*}{$\begin{array}{c}\text { Irrigation } \\
\text { (L/container) }\end{array}$} & \multirow{3}{*}{$\begin{array}{c}\text { Runoff } \\
\text { (L/container) }\end{array}$} & \multirow{2}{*}{\multicolumn{3}{|c|}{ Runoff nutrient loss (mg/container) }} \\
\hline \multirow{2}{*}{$\begin{array}{l}\text { Irrigation } \\
\text { schedule }\end{array}$} & \multirow{2}{*}{$\begin{array}{c}\text { Fertilizer rate } \\
\text { (g/container) }\end{array}$} & & & & & \\
\hline & & & & Nitrogen $^{\mathrm{y}}$ & Phosphorus & Potassium \\
\hline \multicolumn{7}{|c|}{2004 Experiment } \\
\hline $1 \mathrm{~cm}$ & 15 & 43.1 & 33.4 & 546 & 64 & 342 \\
\hline $1 \mathrm{~cm}$ & 30 & 43.2 & 32.3 & 1438 & 158 & 805 \\
\hline ET & 15 & 23.6 & 14.9 & 444 & 47 & 258 \\
\hline \multirow[t]{5}{*}{ ET } & 30 & 23.6 & 13.9 & 1219 & 119 & 631 \\
\hline & Effect $^{\mathrm{x}}$ : & & & & & \\
\hline & Irrigation(I) & $* * *$ & $* * *$ & $* *$ & $* *$ & $* *$ \\
\hline & Fertilizer rate $(\mathrm{F})$ & NS & NS & $* * *$ & $* * *$ & $* * *$ \\
\hline & $\mathrm{F} \times \mathrm{I}$ & NS & NS & NS & NS & NS \\
\hline \multicolumn{7}{|c|}{2005 Experiment } \\
\hline $1 \mathrm{~cm}$ & 10 & 30.4 & 29.4 & 450 & 50 & 514 \\
\hline $1 \mathrm{~cm}$ & 15 & 29.9 & 28.5 & 815 & 90 & 717 \\
\hline ET & 10 & 20.2 & 22.1 & 414 & 46 & 442 \\
\hline \multirow[t]{5}{*}{ ET } & 15 & 20.1 & 22.0 & 733 & 76 & 600 \\
\hline & Effect $^{\mathrm{x}}$ : & & & & & \\
\hline & Irrigation(I) & $* * *$ & $* * *$ & NS & NS & $*$ \\
\hline & Fertilizer rate $(\mathrm{F})$ & NS & NS & $* *$ & $* *$ & $* *$ \\
\hline & $\mathrm{F} \times \mathrm{I}$ & NS & NS & NS & NS & NS \\
\hline
\end{tabular}

Irrigation water was applied at either $1 \mathrm{~cm} \cdot \mathrm{d}^{-1}$ or at a rate proportional to container evapotranspiration (ET) as determined by weighing. An $18 \mathrm{~N}-2.6 \mathrm{P}-10 \mathrm{~K}$ polymer-coated, controlled-release fertilizer was incorporated immediately before planting. Precipitation totaled $7.9 \mathrm{~L} /$ container in 2004 and $26.1 \mathrm{~L} /$ container in 2005

${ }^{y} \mathrm{NO}_{3}-\mathrm{N}+$ total Kjehldahl $\mathrm{N}$ (TKN analysis did not include $\left.\mathrm{NO}_{3}-\mathrm{N}\right)$.

${ }^{\mathrm{x}}$ Week $\times$ irrigation and week $\times$ fertilizer effects were significant for nitrogen, phosphorus, and potassium loss; week $\times$ irrigation effect was significant for irrigation and runoff.

Ns, ${ }^{*}, * *$ Non-significant or significant at $P \leq 0.05$ or 0.01 , respectively. 
Table 3. Nutrient load of runoff collected continuously during 17 weeks of growing Viburnum odoratissimum in $2.4-\mathrm{L}$ containers. ${ }^{\mathrm{z}}$

\begin{tabular}{|c|c|c|c|c|c|}
\hline \multicolumn{2}{|c|}{ Treatment } & \multirow[b]{3}{*}{ Runoff $\left(\mathrm{L} \cdot \mathrm{m}^{-2}\right)$} & \multirow{2}{*}{\multicolumn{3}{|c|}{ Runoff nutrient load $\left(\mathrm{g} \cdot \mathrm{m}^{-2}\right)$}} \\
\hline \multirow{2}{*}{$\begin{array}{l}\text { Irrigation } \\
\text { schedule }\end{array}$} & \multirow{2}{*}{$\begin{array}{c}\text { Fertilizer rate } \\
\text { (g/container) }\end{array}$} & & & & \\
\hline & & & Nitrogen $^{y}$ & Phosphorus & Potassium \\
\hline \multicolumn{6}{|c|}{2004 Experiment } \\
\hline $1 \mathrm{~cm}$ & 15 & 700 & 15.7 & 1.82 & 9.9 \\
\hline $1 \mathrm{~cm}$ & 30 & 680 & 39.0 & 4.27 & 22.3 \\
\hline ET & 15 & 320 & 12.7 & 1.33 & 7.5 \\
\hline \multirow[t]{5}{*}{ ET } & 30 & 300 & 32.2 & 3.12 & 17.1 \\
\hline & Effect $^{\mathrm{x}}$ : & & & & \\
\hline & Irrigation(I) & $* * *$ & $* *$ & $* *$ & $* *$ \\
\hline & Fertilizer rate $(\mathrm{F})$ & NS & $* * *$ & $* * *$ & $* * *$ \\
\hline & $\mathrm{F} \times \mathrm{I}$ & NS & NS & NS & $*$ \\
\hline \multicolumn{6}{|c|}{2005 Experiment } \\
\hline $1 \mathrm{~cm}$ & 10 & 750 & 13.0 & 1.49 & 15.9 \\
\hline $1 \mathrm{~cm}$ & 15 & 720 & 23.2 & 2.58 & 21.7 \\
\hline ET & 10 & 530 & 11.6 & 1.31 & 13.4 \\
\hline \multirow[t]{5}{*}{ ET } & 15 & 520 & 20.2 & 2.13 & 17.9 \\
\hline & Effect $^{\mathrm{x}}$ : & & & & \\
\hline & Irrigation(I) & $* * *$ & NS & NS & $*$ \\
\hline & Fertilizer rate $(\mathrm{F})$ & NS & $* *$ & $*$ & $* *$ \\
\hline & $\mathrm{F} \times \mathrm{I}$ & NS & NS & NS & NS \\
\hline
\end{tabular}

${ }^{\mathrm{z}}$ Irrigation water was applied at either $1 \mathrm{~cm} \cdot \mathrm{d}^{-1}$ or at a rate proportional to container evapotranspiration (ET). An $18 \mathrm{~N}-2.6 \mathrm{P}-10 \mathrm{~K}$ polymer-coated, controlled-release fertilizer was incorporated immediately before planting. Initial container density was 32 containers $/ \mathrm{m}^{2}$, which was reduced to 16 containers $/ \mathrm{m}^{2}$ either 10 weeks after planting (2004) or 13 weeks after planting (2005).

${ }^{y} \mathrm{NO}_{3}-\mathrm{N}+$ total Kjehldahl $\mathrm{N}$ (TKN analysis did not include $\mathrm{NO}_{3}-\mathrm{N}$ ).

${ }^{\mathrm{x}}$ Week $\times$ irrigation and week $\times$ fertilizer effects were significant for nitrogen, phosphorus, and potassium loads; week $\times$ irrigation effect was significant for runoff.

Ns, *, ** Non-significant or significant at $P \leq 0.05$ or 0.01 , respectively.

resulted in $\mathrm{N}, \mathrm{P}$, and $\mathrm{K}$ loads of $17.2,2.13$ and $17.9 \mathrm{~g} \cdot \mathrm{m}^{-2}$, respectively, and CMI resulted in $\mathrm{N}, \mathrm{P}$, and $\mathrm{K}$ loads of $19.4,2.58$, and $21.7 \mathrm{~g} \cdot \mathrm{m}^{-2}$, respectively. Except for K load in 2004, there was no interaction effect between irrigation and fertilizer rate for nutrient loads. Nutrient load values reflect the potential amounts of $\mathrm{N}, \mathrm{P}$, and $\mathrm{K}$ leaving the production area and do not consider factors that can mitigate the potentially negative effects these nutrients can have on the local environment.

\section{Conclusion}

Compared with a fixed-rate irrigation schedule of $1 \mathrm{~cm} \cdot \mathrm{d}^{-1}$, an ET-based irrigation schedule designed to resupply water at a rate proportional to ET reduced the total volume of irrigation water applied by $39 \%$ and the total volume of runoff collected by $42 \%$ when averaged over the two experiments. Irrigation treatment effects varied weekly. For the 2004 experiment, benefits of ETbased irrigation were greatest during the second half of the season when ET rates were low and variable. In contrast, the benefits of ET-based irrigation were greater in the first half of the Spring 2005 experiment when ET rates and precipitation were low. The benefits of ET-based irrigation should be even greater
Beeson, R.C., Jr. 2005. Modeling irrigation requirements for landscape ornamentals. HortTechnology 15:18-22.

Beeson, R.C., Jr. 2006. Relationship of plant growth and actual evapotranspiration to irrigation frequency based on management allowed deficits for container nursery stock. J. Amer. Soc. Hort. Sci. 13:140-148.

Beeson, R.C., Jr. 2010. Response of evapotranspiration of Viburnum odoratissimum to canopy closure and the implications for water conservation during production and in landscapes. HortScience 45:359-364.

Beeson, R.C., Jr. and G.W. Knox. 1991. Analysis of efficiency of overhead irrigation in container production. HortScience 26:848-850.

Beeson, R.C., Jr. and T.H. Yeager. 2003. Plant canopy affects sprinkler irrigation application efficiency of container-grown ornamentals. HortScience 38:1373-1377.

Fare, D.C., M. Halcomb, and S. Mullican. 1999 Application method affects controlled-release fertilizer response in pot-in-pot production. Proc. Southern Nurs. Assoc. Res. Conf. 44:97-102.

Fernandez-Escobar, R., M. Benlloch, E. Herrera, and J.J. Garcia-Novelo. 2004. Effect of traditional and slow-release $\mathrm{N}$ fertilizers on growth of olive nursery plants and $\mathrm{N}$ losses by leaching. Sci. Hort. 101:39-49.

Florida Automated Weather Network. 2010. 3 July 2010. <http://fawn.ifas.ufl.edu/ $>$.

Haman, D.Z., A.G. Smajstrla, and D.J. Pitts. 1997. Uniformity of sprinkler and microirrigation systems for nurseries. Bulletin 321. Florida Cooperative. Extension Service. Institute Food Agricultural Sciences. Univ. Florida, Gainesville, FL.

in nurseries where daily irrigation rates exceed $1 \mathrm{~cm} \cdot \mathrm{d}^{-1}$.

ET-based irrigation had less of an effect on reducing nutrient leaching losses compared with the fixed $1-\mathrm{cm} \cdot \mathrm{d}^{-1}$ rate than it did in reducing the amount of irrigation water applied and runoff collected. Higher concentrations of nutrients were found in runoff from the ET-based irrigation treatment indicating that nutrients that accumulate during periods of low leaching may be leached when periods of greater leaching occur. This supports the observation of Huett (1997) that there is a practical limit to reducing $\mathrm{N}$ leaching under growing conditions where precipitation is likely to be important. This information further supports the conclusion that choosing CRFs with release rates that match plant demand is crucial in minimizing nutrient leaching even with conservative irrigation practices.

\section{Literature Cited}

Barrett, J.E. 1991. Water and fertilizer movement in greenhouse subirrigation systems. Greenhouse Manager 10:89-90.

Beeson, R.C., Jr. 1993. Relationship of potential evapotranspiration and actual evapotranspiration of Rhododendrom sp. 'Formosa'. Proc. Fla. State Hort. Soc. 106:274-276.
Huett, D.O. 1997. Fertiliser use efficiency by containerized nursery plants. 2. Nutrient leaching. Aust. J. Agr. Sci. 48:259-265.

Huett, D.O. and B.J. Gogel. 2003. Longevities and nitrogen, phosphorus, and potassium release patterns of polymer-coated controlled-release fertilizers at $30^{\circ} \mathrm{C}$ and $40^{\circ} \mathrm{C}$. Commun. Soil Sci. Plant Anal. 31:959-973.

Million, J., T. Yeager, and J. Albano. 2007a. Effects of container spacing and fertilizer placement on runoff from overhead-irrigated Viburnum odoratissimum. J. Environ. Hort. 25:61-72.

Million, J., T. Yeager, and J. Albano. $2007 \mathrm{~b}$. Consequences of excessive overhead irrigation on runoff during container production of sweet viburnum. J. Environ. Hort. 25:117-125.

Moutonnet, P. and J.C. Fardeau. 1997. Inorganic nitrogen in soil solution collected with tensionic samplers. Soil Sci. Soc. Amer. J. 61: 822-825.

Schuch, U.K. and D.W. Burger. 1997. Water use and crop coefficients of woody ornamentals in containers. J. Amer. Soc. Hort. Sci. 122:727734.

Tyler, H.H., S.L. Warren, and T.E. Bilderback. 1996. Reduced leaching fractions improve irrigation use efficiency and nutrient efficacy. J. Environ. Hort. 14:199-204.

Welsh, D.F. and J.M. Zajicek. 1993. A model for irrigation scheduling in container-grown nursery crops utilizing management allowed deficit (MAD). J. Environ. Hort. 11:115-118. 